Canadian

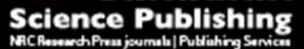

Canadian Journal of Civil Engineering Revue canadienne de génie civil

\title{
OPTIMIZING THE SELECTION OF SUSTAINABILITY MEASURES TO MINIMIZE LIFE-CYCLE COST OF EXISTING BUILDINGS
}

\begin{tabular}{|r|l|}
\hline Journal: & Canadian Journal of Civil Engineering \\
\hline Manuscript ID & cjce-2015-0179.R1 \\
\hline Danuscript Type: & Article \\
\hline Complete List of Authors: & $\begin{array}{l}\text { Abdallah, Moatassem; University of Colorado Denver, Civil Engineering } \\
\text { El-Rayes, Khaled; University of Illinois at Urbana-Champaign, Civil and } \\
\text { Environmental Engineering } \\
\text { Liu, Liang; University of Illinois at Urbana-Champaign, Civil and } \\
\text { Environmental Engineering }\end{array}$ \\
\hline Keyword: & $\begin{array}{l}\text { buildings < Construction, Optimization, Life-cycle Cost, Sustainability, } \\
\text { Upgrade Measures }\end{array}$ \\
\hline & \\
\hline
\end{tabular}

SCHOLARONE ${ }^{1 m}$

Manuscripts 


\title{
OPTIMIZING THE SELECTION OF SUSTAINABILITY MEASURES TO MINIMIZE LIFE-CYCLE COST OF EXISTING BUILDINGS
}

\author{
Moatassem Abdallah a,b, *, Khaled El-Rayes ${ }^{c}$, Liang Liu ${ }^{c}$ \\ a Department of Civil Engineering, University of Colorado Denver, Denver, CO 80222, United States \\ ${ }^{b}$ Department of Structural Engineering, Cairo University, Egypt, \\ ${ }^{c}$ Department of Civil and Environmental Engineering, University of Illinois at Urbana-Champaign, \\ Urbana, IL 61801, United States \\ * Corresponding author. \\ E-mail addresses: moatassem.abdallah@ucdenver.edu (M. Abdallah), elrayes@illinois.edu (K. El-Rayes), \\ and Iliu1@illinois.edu (L. Liu)
}




\section{Abstract:}

Buildings have significant impacts on the environment and economy as they were reported by the World Business Council for Sustainable Development in 2009 to account for $40 \%$ of the global energy consumption. Building owners are increasingly seeking to integrate sustainability and green measures in their buildings to minimize energy and water consumption as well as life-cycle cost. Due to the large number of feasible combinations of sustainability measures, decision makers are often faced with a challenging task that requires them to identify an optimal set of upgrade measures to minimize the building life-cycle cost. This paper presents a model for optimizing the selection of building upgrade measures to minimize the life-cycle cost of existing buildings while complying with owner-specified requirements for building operational performance and budget constraints. The optimization model accounts for initial upgrade cost, operational cost and saving, escalation in utility costs, maintenance cost, replacement cost, and salvage value of building fixtures and equipment, and renewable energy systems. A case study of a rest area building in the state of Illinois in the United States was analyzed to illustrate the unique capabilities of the developed optimization model. The main findings of this analysis illustrate the capabilities of the model in identifying optimal building upgrade measures to achieve the highest savings of building life-cycle cost within a user-specified upgrade budget; and generating practical and detailed recommendations on replacing building fixtures and equipment and installing renewable energy systems.

Keywords: Optimization; existing buildings; energy consumption; life-cycle cost; upgrade measures; sustainability. 


\section{INTRODUCTION:}

Buildings have significant impacts on the environment and economy as they were reported by the World Business Council for Sustainable Development in 2009 to account for $40 \%$ of the global energy consumption (WBCSD 2009). The same study reported that $80 \%$ of the total energy use of buildings is consumed during their operational life while $20 \%$ is consumed during their construction and demolition in six of the world's largest economic regions (Brazil, China, EU, India, Japan and USA) (WBCSD 2009). This highlights the importance of minimizing energy consumption in existing buildings by integrating green and sustainable building measures such as motion sensors, ground source heat pumps, photovoltaic systems, and water saving toilets. Although the integration of these green measures in existing buildings requires additional investments and costs; they are capable of providing significant savings in the life-cycle cost of buildings due to their impact on reducing energy and water consumption as well as building maintenance costs. Due to the large number and combinations of sustainability measures that can be installed in existing buildings, building owners and managers are often faced with a challenging task to select an optimal set of sustainable measures to upgrade their buildings while complying with the limited budget and the existing conditions of their buildings. This highlights the need for developing an optimization model which is capable of selecting optimal sustainable building measures from a set of feasible alternatives based on the allocated upgrade budget and the operational performance of buildings.

Several studies have been conducted to analyze and evaluate the performance of implementing various sustainable measures in buildings. These studies analyzed energy and cost savings that can be achieved by installing motion sensors in commercial buildings (VonNeida, Maniccia, and Tweed 2001); energy savings and performance of energy efficient lighting in buildings and streets (Henderson 2009; Ryckaert et al. 2012; Lippert 2009; Roberts 2010; Narendran and Gu 2005); feasibility of installing photovoltaic systems and wind power turbines to generate renewable energy at building sites (Matthews, Cicas, and Aguirre 2004; 
Chapman and Wiczkowski 2009; James et al. 2011); energy and cost savings of energy efficient HVAC systems and ground source heat pumps in buildings (Bloomquist 2003; Bloomquist 2001; Chiasson 2006; Long Ni et al. 2011; Blumsack, Brownson, and Witmer 2009); water savings of water efficient plumbing fixtures in buildings (GAO 2000). Other research studies focused on developing optimization models and decision support systems for improving the performance of existing and new buildings, including optimizing structural and architecture aspects, and the envelope design of new buildings (Fialho, Hamadi, and Schoenauer 2011; Tuhus-Dubrow and Krarti 2010; Bichiou and Krarti 2011); evaluating existing building conditions and identifying optimal decisions of building renovations (O'Donnell et al. 2005; Simmons et al. 2013; Brandt and Rasmussen 2002; Kaklauskas, Zavadskas, and Raslanas 2005; Juan, Gao, and Wang 2010; Zhang et al. 2013); and optimizing the selection of existing building upgrade decisions to minimize LEED certification costs (Bastian 2011). Despite the significant contributions of these studies, there is no reported research that focused on optimizing the selection of sustainability measures, including light systems, motion sensors, HVAC systems, water heaters, hand dryers, vending machines and refrigerators, water coolers and PCs, solar PV systems, water faucets, urinals, and toilets in order to minimize the life-cycle cost of existing buildings while complying with specified upgrade budgets and building operational performance that specify the required levels of lighting, space heating and cooling, and water heating. Furthermore, there is no reported studies that considered the aforementioned list of sustainability measures simultaneously and accounted for all components of their life-cycle cost including initial upgrade costs, annual energy and water costs, escalation in utility costs, annual maintenance and repair costs, replacement costs, electricity savings due to the generation of renewable electricity, and the salvage value. The aforementioned list of sustainability measures are integrated in the optimization model to represent the most common feasible upgrade measures for existing buildings that do not require major reconstruction or renovation of the building envelope while enabling significant reduction in the building life-cycle cost. 


\section{OBJECTIVE}

The objective of this paper is to present an optimization model that is capable of selecting building sustainable measures to minimize the life-cycle cost of existing buildings while maintaining buildings operational performance and complying with an available upgrade budget. The objective of this model is to support building owners of residential and commercial building in their ongoing efforts to identify the required upgrade measures to minimize the life-cycle cost of their existing buildings by reducing the annual energy, water, maintenance, and replacement costs. The optimization model is developed in three main phases: (i) formulation phase which formulates the model decision variables, objective function and constraints; (ii) implementation phase which implements the model using Genetic Algorithms and identifies its input and output data using a database of building sustainability measures; and (iii) performance evaluation phase which analyzes and refines the performance of the optimization model using a case study of an existing public building, as shown in Figure 1. The following sections describe these three development phases.

\section{FORMULATION PHASE}

The decision variables of the developed optimization model are designed to represent the most common upgrade measures for existing buildings without requiring major reconstruction or renovation of its building envelope while enabling significant reduction in the building life-cycle cost. This covers feasible alternatives for upgrading building fixtures and equipment and the use of renewable energy systems, including combinations of lighting bulbs and fixtures, motion sensors, HVAC equipment, water heaters, hand dryers, vending machines and refrigerators, water coolers and PCs, solar panels, solar inverters, water faucets, urinals, toilets, and percentage of renewable energy that can be generated at the building site to offset its electricity demand. These building upgrade measures are represented by two types of 
decision variables: (1) $X_{j}^{i}$ which is an integer decision variable representing the selection of building fixture or equipment $X_{j}$ in building location $i$ such as a specific building room or space from a set of feasible alternatives; and (2) $X_{R E}$ which is a real decision variable representing the percentage of annual renewable energy to the annual building energy demand that need to be generated at the building site, as shown in Figure 2. The $i$ values of the decision variables $X_{j}^{i}$ depend on the number of locations where a fixture or equipment $\mathrm{j}$ is located in the building, and the values of $j$ depend on the type of the building fixture or equipment, as shown in Figure 2. For example, $X_{1}^{10}$ represent a combination of light fixture and bulbs at room or space \# 10 of the building.

The objective function of the developed optimization model is designed to minimize the Life-Cycle Costs (LCC) of existing buildings which is calculated by summing up the LCC of all building fixtures, equipment, and sustainability measures; as shown in Equation (1), Equation (2), and Equation (3). The LCC of a building fixture or equipment can be calculated by summing up all its costs during the study period of the building (Fuller and Petersen 1996), including initial costs, annual energy and water costs, annual maintenance and repair costs, replacement costs, electricity savings due to the generation of renewable electricity, and salvage value, as shown in Figure 3. The initial costs include any capital investment for upgrading the building with sustainable measures that include purchase and installation costs. The energy and water costs are calculated based on energy and water consumption, utility rates, and price projection. The electricity consumption of lighting, hand dryers, vending machines, refrigerators, PCs, and water coolers are calculated based on the characteristics of the energy devices and operational schedule and usage of the building. For example, the energy consumption of hand dryers is calculated based on capacity of the hand dryer, average drying time according to the manufacturer, and number of uses per day, as shown in Equation (4). The energy consumption of the HVAC systems and water heaters are calculated in the model using the QUick Energy 
Simulation Tool "eQUEST" (USDOE 2013). The water consumption of the building is calculated based on the characteristics of the plumbing fixtures, type of building, and number of occupants. Maintenance and repair costs are calculated based on available guidelines, such as the Facility Maintenance and Repair Cost Reference (Whitestone Research 2013). Replacement costs are calculated based on the purchase and installation costs of building fixtures or equipment and estimated life of the building fixture or equipment. The salvage value is estimated based on the remaining value of the building fixture or equipment at the end of its life (Fuller and Petersen 1996). In order to calculate the LCC of existing buildings, all the aforementioned costs of building fixtures, equipment, and sustainable measures are converted to present worth based on discount/interest rate. This discount/interest rate can be determined based on the investor's rate of return.

$B L C C=\sum_{j=1}^{10} \sum_{i=1}^{N_{j}} \operatorname{LCC}\left(X_{j}^{i}\right) * n_{j}^{i}+\sum_{i=1}^{2} \operatorname{LCC}\left(X_{11}^{i}, X_{12}^{i}\right)$

Equation (1)

Where: $B L C C$ : is building life-cycle cost, $N_{j}$ is number of locations of building fixture or equipment $X_{j} ; \operatorname{LCC}\left(X_{j}^{i}\right)$ is LCC of building fixture or equipment $X_{j}^{i}$ which include upgrade costs, annual energy and water costs, escalation in utility costs, maintenance costs, replacement costs, and salvage value, as shown in Equation (2); and $n_{j}^{i}$ is number of fixtures of equipment $j$ at location $i ; \operatorname{LCC}\left(X_{11}^{i}, X_{12}^{i}\right)$ is life life-cycle cost of photovoltaic system at building roof $(i=1)$ or on the ground $(i=2)$ which include upgrade costs, maintenance costs, replacement costs, annual electricity savings, and salvage value, as shown in Equation (3).

$$
\begin{aligned}
& \operatorname{LCC}\left(X_{j}^{i}\right)=U C\left(X_{j}^{i}\right)+O C\left(X_{j}^{i}\right) * P A+\sum_{r=1}^{R} R C_{r}\left(X_{j}^{i}\right) * P F R_{r}-\sum_{r=1}^{R} S V_{r}\left(X_{j}^{i}\right) * P S F_{r} \quad \forall j \quad \text { Equation (2) } \\
& =1 \text { to } 10 .
\end{aligned}
$$


Where: $U C\left(X_{j}^{i}\right)$ is upgrade cost of building fixture or equipment $X_{j}^{i} ; \operatorname{OC}\left(X_{j}^{i}\right)$ is annual operational cost of building fixture or equipment $X_{j}^{i}$ which include energy or water costs and maintenance costs; $P A$ is present worth factor of an arithmetic gradient series which can be calculated based on annual interest rate, escalation rate in utility bills, and number of years of the study period; $R C\left(X_{j}^{i}\right)$ is replacement cost of building fixture or equipment $X_{j}^{i} ; P F R_{r}$ is present worth of the future replacement cost $r$ of building fixture or equipment $X_{j}^{i}$ which depends on its expected future replacement time and the annual interest rate; $R$ is total number of replacements that depends on the expected service life of the building fixture or equipment in years and the duration of the study period $\mathrm{n}$ in years; $S V\left(X_{j}^{i}\right)$ is salvage value of building fixture or equipment $X_{j}^{i}$; and $P F S_{r}$ is present worth of the building fixture or equipment salvage value which can be calculated based on annual interest rate and number of years of the study period.

$$
\begin{aligned}
\operatorname{LCC}\left(X_{11}^{i}, X_{12}^{i}\right)= & U C^{i}\left(X_{11}^{i}, X_{12}^{i}\right)+\operatorname{OC}\left(X_{11}^{i}, X_{12}^{i}\right) * P A+\sum_{r=1}^{R} R C_{r}\left(X_{11}^{i}\right) * P F R_{r} \\
& +\sum_{r=1}^{R} R C_{r}\left(X_{12}^{i}\right) * P F R_{r}-\sum_{r=1}^{R} S V_{r}\left(X_{11}^{i}\right) * P S F_{r}-\sum_{r=1}^{R} S V_{r}\left(X_{12}^{i}\right) * P S F_{r} \\
& -E S\left(X_{11}^{i}, X_{12}^{i}\right) * P A
\end{aligned}
$$

Where: $U C\left(X_{11}^{i}, X_{12}^{i}\right), O C\left(X_{11}^{i}, X_{12}^{i}\right), R C\left(X_{11}^{i}\right), R C\left(X_{12}^{i}\right), S V\left(X_{11}^{i}\right)$, and $S V\left(X_{12}^{i}\right)$ are upgrade cost, operational cost, replacement cost of solar panels, replacement cost of inverters, salvage value of solar panels, and salvage value of solar inverters, respectively; $\operatorname{ES}\left(X_{11}^{i}, X_{12}^{i}\right)$ is electricity savings of photovoltaic system $i$.

$H D E C=\sum_{i=1}^{N_{5}} W\left(X_{5}^{i}\right) * D\left(X_{5}^{i}\right) * U P D * 365$

Equation (4) 
Where: HDEC: is hand dryers electricity consumption in Kilowatt-hour, $N_{j}$ is number of locations of hand dryers, $W\left(X_{5}^{i}\right)$ electricity consumption in kilowatts of hand dryer $X_{5}$ at location $i$ of the building, $D\left(X_{5}^{i}\right)$ is average drying time in hours of hand dryer $X_{5}^{i}, U P D$ is number of uses per day, and 365 is the number of days per year to calculate the annual energy consumption of hand dryers.

In order to ensure that the developed optimization model is providing feasible and practical solutions, four types of optimization constraints were integrated: (i) upgrade budget constraint, (ii) operational performance constraint, (iii) photovoltaic system constraints, and (iv) decision variables constraint. The upgrade budget constraint is integrated in the model to ensure that the upgrade cost of replacing existing building fixtures and equipment or installing renewable energy systems do not exceed the available upgrade budget, as shown in Equation (5).

$B U C \leq \sum_{j=1}^{10} \sum_{i=1}^{N_{j}} U C\left(X_{j}^{i}\right) * n_{j}^{i}+\sum_{i=1}^{2} U C^{i}\left(X_{11}^{i}, X_{12}^{i}\right)$

Equation (5)

Where: $B U C$ : is building upgrade costs.

The operational performance constraint is integrated in the model to ensure that the operational performance of the building is maintained after performing replacements of building fixtures and equipment such as light levels in lumens output per fixture, space heating capacity in KBTUs, space cooling capacity in tons, and water heating capacity in gallons. The developed model is also designed to provide flexibility to decision makers by allowing them to identify a predefined reduction in the existing building performance. For example, the optimization model maintains the cooling and heating performance of buildings or allowing a predefined reduction by allowing the replacement of HVAC equipment with equivalent or reduced cooling and heating capacities, as shown in Equation (6) and Equation (7). Similarly, the optimization model is 
designed to maintain similar performance or allow a predefined reduction from the existing operational performance for interior lighting, exterior lighting, and water heaters. It should be that these predefined reductions, if any, should be carefully analyzed and specified by the user to ensure that the building performance after completing the building upgrade will satisfy all its operational requirements. For example, if the user specify that the allowed percentage reduction of the HVAC system cooling capacity is $10 \%$, then the model will consider all HVAC systems that provide $90 \%$ or more cooling capacity than the capacity of the existing HVAC system as feasible alternatives without verifying whether they are capable of satisfying the required building cooling loads or not.

$\sum_{i=1}^{N_{4}} \operatorname{CoolC}\left(E_{4}^{i}\right) *\left(1-\mathrm{R}_{c}\right) \geq \operatorname{CoolC}\left(X_{4}^{i}\right)$

Equation (6)

$\sum_{i=1}^{N_{4}} \operatorname{HeatC}\left(E_{4}^{i}\right) *\left(1-\mathrm{R}_{h}\right) \geq \operatorname{HeatC}\left(X_{4}^{i}\right)$

Equation (7)

Where: $\operatorname{CoolC}\left(E_{4}^{i}\right)$ is the cooling capacity of existing HVAC system $E_{4}$ at location $i$ of the building, $\mathrm{R}_{c}$ : is the allowed percentage reduction of the $\mathrm{HVAC} E_{4}^{i}$ cooling capacity, $\operatorname{CoolC}\left(X_{4}^{i}\right)$ is the cooling capacity of the possible replacement for the HVAC system $E_{4}$ with $X_{4}$ at location $i$ of the building, $\operatorname{HeatC}\left(E_{4}^{i}\right)$ is the heating capacity of existing HVAC system $E_{4}$ at location $i$ of the building, $\mathrm{R}_{h}$ : is the allowed percentage reduction of the HVAC $E_{4}^{i}$ heating capacity, and $\operatorname{HeatC}\left(X_{4}^{i}\right)$ is the heating capacity of the possible replacement for the HVAC system $E_{4}$ with $X_{4}$ at location $i$ of the building.

The photovoltaic system constraints are integrated in the model to comply with the design requirements of the grid connected photovoltaic system. For example, the model integrates a constraint to ensure that the selected components of the photovoltaic systems are capable of generating the specified percentage of renewable energy $X_{R E}$ that can be generated at the building site, as shown in Equation (8). Similarly, other constraints were integrated in the 
model to comply with the design requirements of the photovoltaic system, including the required number and area of parallel and series panels, and number of inverters. It should be noted that the model is designed to enable decision makers to consider two photovoltaic systems which can be placed on building roof $(i=1)$ and/or on the ground $(i=2)$.

$X_{R E} * B E C \leq \sum_{i=1}^{2} \sum_{m=1}^{12} A D S I_{i, m} * D_{m} * w\left(X_{11}^{i}\right) * \mathrm{n}_{11}^{i} * t_{m, X_{11}^{i}} * d * e_{i, X_{12}^{i}} * w * 10^{-3} \quad$ Equation (8)

Where: $B E C$ is building annual electricity consumption in $\mathrm{Kwh}, A D S I_{i, m}$ is average daily solar insolation in month $m$ at location $i$ of the building based on the tilt and orientation angle of solar panels and location of the building in peak sun hours which can be calculated based on available online tools such as National Renewable Energy Laboratory and GAISMA (NREL 2010; GIASMA 2014), $D_{m}$ is number of days per month $m, w\left(X_{11}^{i}\right)$ is energy production of single solar panel $X_{11}^{i}$ at location $i$ of the building in watts, $\mathrm{n}_{11}^{i}$ is number of solar panels at location $i$ of the building, $t_{m, X_{11}^{i}}$ is derating factor of the daily temperature effect in month $m$ for solar panel $X_{11}^{i}$, on the electricity production of solar panels $X_{11}^{i}, \mathrm{~d}$ is derating factor of the dirt and snow effect on the electricity production of solar panels, $e_{i, X_{12}^{i}}$ is derating factor of the inverter efficiency $X_{12}^{i}$ for converting DC current to AC current at location $i$ of the building, $w$ is derating factor of DC and AC wiring in a PV system, 2 is number of photovoltaic systems at the building site, and $10^{-3}$ is a conversion factor that converts the generated renewable electricity from wh to Kwh.

The decision variables constraints are integrated in the model to set the boundaries of all the decision variables. $X_{j}^{i}$ decision variables are set with a lower bound of one to represent the first feasible alternative for the fixture or equipment at location $i$ of the building, and an upper bound to represent the total number of alternatives at location $i$ of the building. For example, if the model database (see implementation section) includes 1500 alternatives of light fixtures, $\mathrm{X}_{1}^{\mathrm{i}}$ 
is set with a lower bound of one to represent the first alternative light fixture at location i, and upper bound of 1500 to represent that there are 1500 alternative light fixtures at location i of the building. Any value between 1 and 1500 identifies a unique light fixture alternative that the model can select and analyze its performance during the optimization computations.

\section{IMPLEMENTATION PHASE}

The implementation of the developed optimization model was performed in three main steps: (i) performing the optimization computations using genetic algorithms; (ii) specifying the model input and output data; and (iii) creating databases for building fixtures, equipment, and components of renewable energy systems, as shown in Figure 4.

The computations of the developed optimization model are performed using Genetic Algorithms (GAs) due to its capability of (1) modeling non-linearity and step changes in the objective function and constraints of the model, (2) identifying optimal solutions for this type of problem in a reasonable computational time, and (3) efficiently modeling this specific optimization problem with the least number of decision variables and constraints even for large buildings and databases (Aytug and Koehler 1996; Greenhalgh and Marshall 2000; Pendharkar and Koehler 2007; Goldberg 1989). The developed optimization model uses the commercial software Evolver add-on for MS Excel to perform the GA computations. MS Excel VBA is used to manage and coordinate between Evolver and eQUEST to identify the optimal solution of the problem.

The model is designed to perform replacements of building fixtures and equipment with more energy and water efficient devices. The solution process starts by searching for feasible replacements of HVAC equipment and water heaters from an integrated database in the model, as shown in Figure 4. This process searches for and extracts all feasible alternatives of HVAC equipment and water heaters from the database that have capacities within a specified range of 1 to 1.1 of the existing capacities of the building equipment. It should be noted that, the model assumes that the existing HVAC systems satisfy the building needs of space heating and 
cooling. After identifying those feasible replacements, input files are generated automatically by the developed optimization model for eQuest based on the identified feasible alternatives for HVAC systems and water heaters. eQuest is used to run all these input files to calculate the energy consumption of the building for all its feasible replacements, which are then stored in a database where it can be recalled and used during the optimization process. It should be noted that the generated input files of eQuest are created with the energy loads of all the other existing fixtures such as lighting and hand dryers loads to account for the interaction of building systems in calculating the energy consumption of the building. Furthermore, the calculation of energy consumption for all feasible HVAC systems and water heaters are performed before GA computations to significantly reduce the computation time of the model, as shown in Figure 4. The optimization computational time is significantly reduced by executing three simulation runs of each feasible HVAC system, one run including the existing building systems, another run with the most efficient light systems, and a third run with the most efficient loads of other devices and equipment. During the optimization computations, the energy consumption of the HVAC system can be calculated approximately based on the selected building systems and the three aforementioned simulation runs. The difference between the approximation and exact results during the calculation of the energy consumption of the HVAC systems were found to be less $1 \%$ in the analyzed case study. Accordingly, the computational time of the model is significantly reduced as it can retrieve the energy consumption of the HVAC systems and water heaters from the model database rather than running eQuest for each possible solution during the GA computations.

The GA computations in the model start by generating a population of random solutions by replacing all the existing fixtures and equipment with feasible alternatives from the model databases. The fitness of these solutions is evaluated based on the building life-cycle cost and model constraints. Solutions that satisfy all the model constraints and achieve low building lifecycle cost are identified as solutions with high fitness values. On the other hand, solutions that 
do not satisfy the model constraints or have high building life-cycle cost are identified as infeasible solutions or solutions with low fitness values, respectively. Solutions with high fitness values are ranked and sorted based on their building life-cycle cost. The GA operators of selection, cross over, and mutations are then applied and a new set of solutions are generated with potential for lower life-cycle cost. This process is iteratively repeated until a predefined number of iterations is completed or no further improvements is achieved within a predefined number of iterations, as shown in Figure 5. It should be noted that, the initial population of the problem and the termination condition are crucial to identify the optimal solution of the problem in a reasonable computational time where they can be specified based on the length of the GA string. The length of the GA string $(g)$ can be identified based on the number of building decision variables and feasible building fixtures and equipment. It should be noted that, the identification of GA parameters (population size, crossover rate, mutation rate, and iterations) that leads to the optimal solution of the problem in the shortest computational time is challenging, however, existing literature recommends that minimum population size and number of iterations should be $2 g / 1.4$ and $2 g$, respectively (Thierens, Goldberg, and Pereira 1998; Reed, Minsker, and Goldberg 2000).

The developed optimization model was implemented in a spreadsheet environment to facilitate the input of all necessary data and the generation of results and action reports. The input data of the developed model are designed to include (i) building characteristics such as geometry, location, building envelop and interior construction, doors and windows, allocation of building activities, visitation rate, and building operational schedule; (ii) selection of building fixtures and equipment from the model databases; (iii) billing rates for electricity, gas and water consumption in $\$ / \mathrm{Kwh}, \$ /$ therm, and $\$ /$ gallon, respectively; and (iv) study period, annual discount rate and escalation in utility rates, as shown in Figure 4. The developed model is designed to allow decision makers to select building fixtures and equipment from the created databases to facilitate and minimize building input data where the model analyzes the 
replacement of these fixtures and equipment during the optimization process. The output results of the developed optimization model is designed to include (i) building life-cycle cost, operational costs, and building annual energy and water consumption before and after minimizing the life-cycle cost of the building, (ii) upgrade costs and payback period after minimizing the life-cycle cost of the building, and (iii) action report which includes detailed recommendations for replacing existing building fixtures and equipment based on the results of the optimization model, as shown in Figure 4.

The developed optimization model is integrated with several databases that include products of building fixtures, equipment, components of renewable energy systems. These databases include general product data, cost data, energy and water characteristics data, and physical characteristics of exterior lighting fixtures and bulbs, interior lighting fixtures and bulbs, motion sensors, hand dryers, HVAC equipment, water heaters, vending machines and refrigerators, general devices such as PCs and water coolers, solar panels, solar inverters, water faucets, urinals, and toilets. For example, the general product characteristics, cost data, energy characteristics, and physical properties of 10 interior light bulbs in the lighting database of the developed model are shown in Figure 6. Furthermore, the general product characteristics, cost data, energy characteristics of 6 solar panels and 8 inverters that are used in the case study are shown in Figure 7 and Figure 8, respectively. The products of building fixtures and equipment and their costs in the integrated databases are collected from manufacturers and retailers. The installation costs of these building fixtures and equipment were calculated using RSMeans building construction cost data (RSMeans 2013). The model is designed to perform replacement for the existing building fixtures and equipment with sustainable measures from the integrated databases. It should be noted that, the developed optimization model and its databases are designed with the flexibility of integrating new and updated sustainability measures. This illustrates the practicality of the model and its capability to continuously 
minimize the life-cycle cost of existing buildings as upgrade budgets are secured and more sustainable measures become available in the market.

\section{PERFORMANCE EVALUATION PHASE}

A case study of an existing highway rest area building was analyzed to illustrate the use of the developed optimization model, demonstrate its newly developed optimization capabilities, and evaluate its performance. Built in 1980 , the analyzed building has a total area of 3,570 square feet with approximately 840 thousand annual visitors according to a statistical analysis that was conducted in 2009. The rest area building includes lobby, women's bathroom, men's bathroom, mechanical room, storage room, travel information desk, and technician office. The building has also a parking lot for visitors that accommodate cars and semi-trucks, and a large landscaped area and outdoor picnic tables. The building equipment and systems that have the highest share of its operational costs include interior and exterior lighting, HVAC system, water heater, hand dryers, vending machines, water coolers, personal computers, surveillance system, water faucets, urinals, and toilets. This case study was selected to evaluate the model performance due to its high operational and life-cycle cost that are caused by its inefficient energy and water fixtures, its continuous operational schedule throughout the year, and its high visitation rates.

In order to minimize the life-cycle cost of this building using the developed model, its required input data were identified and provided to the model, as shown in Figure 4. This input data was obtained from the building drawings and from a site visit of the building to identify (i) the types of services provided by the rest area; (ii) the conditions and characteristics of its appliances and fixtures; and (iii) potential savings and energy-efficiency measures that can be implemented in the building. A sample of the input data that summarizes the main building characteristics is shown in Table 1 . The electricity, gas, and water billing rates as well as the discount rate are inputted in the model based on the obtained energy and water bills of the previous year and average discount rates, as shown in Table 2. The input data of building 
fixtures and equipment were identified based on the data collected during the site visit and by selecting these fixtures and equipment from the model databases, as shown in Table 3 . These databases include all the needed data by the decision maker to select building fixtures and equipment, and the required data by the model to perform the optimization computations. The owner-specified requirements of the building operational performance allowed $5 \%$ reduction in the fixtures light levels and no reduction in the capacities of the HVAC system and water heater. The rest area building was modeled with 42 decision variables that resulted in a search space of $7.3^{*} 10^{30}$. This search space represents all possible combinations of the available alternatives in this case study and can be calculated by multiplying the number of available alternatives $A_{s}$ of each of these 42 decision variables (s) by each other, as shown in Equation (9). The number of available alternatives $A_{s}$ depends on the type of decision variable. For example, the number of alternatives $A_{s}$ for the light fixtures and the hand dryers decision variables in this case study was 1800 and 10 , respectively.

Search Space $=\prod_{s=1}^{s=42} A_{s}$

Equation (9)

The developed model was used to optimize the building upgrade decisions for the rest area building to minimize its life-cycle cost for a study period of 40 years while considering various upgrade budgets that ranged from $\$ 10 \mathrm{~K}$ to $\$ 125 \mathrm{~K}$. The developed model was able to identify the minimum life-cycle cost for all the specified upgrade budgets, as shown in Figure 9. For example for the specified upgrade budget of $\$ 25,000$, the model identified a minimum lifecycle cost of $\$ 746,032$ with annual savings of $\$ 15,365$, and payback period of 1.61 year, as shown in Figure 9 for solution (a). Based on the results of the model for various upgrade budgets, the model was able to select building upgrade measures that achieve the highest savings of building life-cycle cost within the least specified upgrade budget (i.e. $\$ 10 \mathrm{~K})$. As the upgrade budget increases, the model selected additional measures that can further reduce the life-cycle cost of the building, as shown in Figure 9. The population size that was used to 
perform the optimization computations is 300 with 0.3 and 0.6 crossover and mutation rates, respectively. The model was set to terminate the optimization computations when 40,000 trials are reached with no improvements in the model objective function. The computations of the model were performed using a Personal Computer (PC) with Intel Core(TM) 2 Duo $2.93 \mathrm{GHz}$ processor and 4GB RAM. Each simulation run required 30 seconds to be called and completed. The total computational time of the optimization and simulation for solution (a) was 4 hours and 5 minutes, including a total of 45,500 trials with only 19,208 valid trials. The optimal solution was identified 30 minutes after starting the optimization and then the model spent 3 hours and 35 minutes to search for better solution before terminating the computations, as shown in Figure 5. Each trail of the optimization required 0.31 seconds to be completed, and therefore the brute force exhaustive search will require $0.31^{\star} 7.3^{*} 10^{30} \mathrm{sec} .\left(2.7^{*} 10^{25}\right.$ days $)$. This highlights the efficiency and effectiveness of the developed optimization model that was able to identify optimal solution (a) for this case study (see Figure 5 ) in 4 hours and 5 minutes compared to the exhaustive search time that is estimated to take $2.7^{\star} 10^{25}$ days or $7.3^{*} 10^{22}$ years.

The optimization model also provides the capability of generating an action report that provides detailed recommendations on the building fixtures and equipment. The report also identifies the fixtures and equipment that need to be replaced or the renewable energy systems that need to be installed based on the optimization results. For example, the model provided detailed recommendations for replacing existing light bulbs and fixtures as well as plumbing fixtures, as shown in Table 4 and Table 5, respectively. Furthermore, the model is designed to show a comparison of building energy and water cost before and after minimizing the building life-cycle cost, as shown in Figure 10. It should be noted that the model did not recommend replacements of exterior lighting bulbs and fixtures as the available alternatives in the databases cannot provide the required lumen level with lower energy consumption. Similarly, the model did 
not recommend replacements for water faucets as the existing faucets have the lowest discharge rate in the model database.

\section{Limitations and Future Work}

The present optimization model in this study is designed to support building owners in their ongoing efforts to identify the required upgrade measures to minimize the life-cycle cost of existing buildings by reducing the annual energy, water, maintenance, and replacement costs. The present model is designed for buildings that needs to remain in use and operational during the upgrade period and therefore the model focuses on optimizing the selection of upgrade measures that do not require major renovation or reconstruction of existing buildings that may disrupt its ongoing operation. Accordingly, the upgrade measures in the present model are limited to light systems, motion sensors, HVAC systems, water heaters, hand dryers, vending machines and refrigerators, water coolers and PCs, solar PV systems, water faucets, urinals, and toilets. Future expansion of the model may consider other types of buildings that permit disruption of its ongoing use and operation. For this type of buildings, future expansion of the model can consider additional upgrade measures such as building envelope, windows and doors, solar water heaters, and solar tube lighting. Furthermore, the developed optimization model focuses on optimizing the life-cycle cost of existing buildings. Future expansion of the model can extend its scope to include optimizing the life-cycle cost of new buildings.

\section{SUMMARY AND CONCLUSIONS}

An optimization model was developed to enable the selection of an optimal set of sustainability measures for existing buildings in order to minimize their life-cycle cost while complying with the limited availability of upgrade budgets. The model is designed to identify this optimal set of sustainability measures from feasible alternatives that include renewable energy systems such as solar panels, energy efficient equipment and systems such as LED lighting and efficient HVAC systems, and water-saving plumbing fixtures such as efficient faucets and toilets. The model minimizes building life-cycle costs, including sustainability measures upgrade 
costs, energy and water costs, escalation in utility costs, maintenance costs, replacement costs, annual savings due to generated electricity from renewable energy systems, and salvage values. The initial investment, maintenance, and replacement costs of building fixtures and equipment are obtained from an expandable database that includes all the required data such as available options of sustainable measures on the market. The model calculates the energy costs of the HVAC systems and water heaters in the building using an energy simulation program (eQuest) and utility rates. It also calculates the electricity cost of building fixtures such as lighting, hand dryers, vending machines, personal computers, and water coolers based on the characteristics of these fixtures, their operational schedule, and utility rate.

The optimization computations in the model were performed using Genetic Algorithms (GA) due to the non-linearity of the objective function and constraints. The optimization model was implemented in a spreadsheet environment to facilitate the input of all necessary data and the generation of results and action reports. An application example of an existing rest area building was analyzed to evaluate the performance of the developed model. The results of this analysis illustrated that model was able to identify an optimal set of sustainability for each of the specified upgrade budgets that ranged from $\$ 10 \mathrm{~K}$ to $\$ 125 \mathrm{~K}$. The model is designed to provide the optimization results in a graphical and tabular format which include: (i) life-cycle costs, operational costs, upgrade costs, and payback period; (ii) recommendations for replacing existing building fixtures and equipment based on the optimization results, and (iii) building energy and water cost before and after optimizing the building performance. The developed model is capable of minimizing the life-cycle cost of existing residential and commercial buildings at any location. The model is designed to account for the location of the building based on the weather conditions that can be integrated in eQuest energy simulation software. The new and unique capabilities of the developed model demonstrate a new integrated approach that will be useful to building owners and managers in their ongoing efforts to reduce the life-cycle cost of existing buildings and minimize their energy and water consumption. The primary contribution 
of this research is its new methodology for optimizing the selection of building upgrade measures to minimize the life-cycle cost of existing buildings while complying with ownerspecified requirements for building operational performance and budget constraints. Future expansion of the model and more in-depth analysis are needed to further study the impact of (1) integrating additional upgrade measures for existing buildings such as building envelope, windows and doors; and (2) optimizing the design of new buildings. 


\section{REFERENCES}

Aytug, Haldun, and Gary J. Koehler. 1996. "Stopping Criteria for Finite Length Genetic Algorithms.” INFORMS Journal on Computing 8 (2). INFORMS: 183-191. doi:10.1287/ijoc.8.2.183.

Bastian, Nathaniel D. 2011. "Optimizing Army Sustainability at Fort Bragg: A Case Study Connecting Life-Cycle Cost Analysis with Leadership in Energy and Environmental Design for Existing Buildings." Engineering Management Journal 23 (2): 42-53.

Bichiou, Youssef, and Moncef Krarti. 2011. "Optimization of Envelope and HVAC Systems Selection for Residential Buildings." Energy and Buildings 43 (12): 3373-3382. http://www.sciencedirect.com/science/article/pii/S0378778811003811.

Bloomquist, R Gordon. 2001. "The Economics of Geothermal Heat Pump Systems for Commercial and Institutional Buildings." In International Scientific Conference "Geothermal Energy in Underground Mines," 25-40. Ustroñ, Poland. https://www.geothermallibrary.org/index.php?mode=pubs\&action=view\&record=8000188.

Bloomquist, R.Gordon. 2003. "Geothermal Space Heating." Geothermics 32 (4-6): 513-526. doi:http://dx.doi.org/10.1016/j.geothermics.2003.06.001.

Blumsack, S., J. Brownson, and L. Witmer. 2009. "Efficiency, Economic and Environmental Assessment of Ground Source Heat Pumps in Central Pennsylvania." In 2009 42nd Hawaii International Conference on System Sciences, 1-7. IEEE. doi:10.1109/HICSS.2009.179.

Brandt, E., and M.H. Rasmussen. 2002. "Assessment of Building Conditions." Energy and Buildings 34 (2): 121-125. doi:10.1016/S0378-7788(01)00102-5.

Chapman, Patrick, and Piotr Wiczkowski. 2009. Wind-Powered Electrical Systems-Highway Rest Areas, Weigh Stations, and Team Section Buildings. Urbana. Urbana: Illinois Center for Transportation. http://128.174.2.147/publications/report files/FHWA-ICT-09-034.pdf.

Chiasson, Andrew. 2006. Life-Cycle Cost Study of a Geothermal Heat Pump System. Klamath Falls, OR, USA: Geo-Heat Center, Oregon Institute of Technology. http://geoheat.oit.edu/toa/toa1task2.pdf.

Fialho, Álvaro, Youssef Hamadi, and Marc Schoenauer. 2011. "Optimizing Architectural and Structural Aspects of Buildings towards Higher Energy Efficiency." In GECCO 2011 Workshop on GreenIT Evolutionary Computation. http://hal.inria.fr/inria-00591930.

Fuller, S. K., and S. R. Petersen. 1996. Life-Cycle Costing Manual for the Federal Energy Management Program. Edited by S. R. Fuller, S. K.; Petersen. 1995th ed. Gaithersburg, MD: National Institute of Standards and Technology (NIST). http://fire.nist.gov/bfrlpubs/build96/art121.html.

GAO. 2000. Water-Efficient Plumbing Fixtures Reduce Water Consumption and Wastewater Flows. Washington, D.C. http://www.gao.gov/products/RCED-00-232. 
GIASMA. 2014. "Solar Energy and Surface Meteorology." GIASMA. http://www.gaisma.com/en/.

Goldberg, DE. 1989. Genetic Algorithms in Search, Optimization, and Machine Learning. New York: Addison-Wesley Longman Publishing Co., Inc. http://is-this-book-good.info/wpcontent/uploads/pdfs/Genetic Algorithms in Search Optimization and Machine Learning by David E Goldberg - Great Start To Your Journey In Genetic Algorithms.pdf.

Greenhalgh, David, and Stephen Marshall. 2000. "Convergence Criteria for Genetic Algorithms." SIAM Journal on Computing 30 (1). Society for Industrial and Applied Mathematics: 269282. doi:10.1137/S009753979732565X.

Henderson, Robert. 2009. "LED Street Lighting." LED Street Lighting. http://www.progressenergy.com/assets/www/docs/home/LED-streetlight-test-project-report.pdf.

James, Ted, Alan Goodrich, Michael Woodhouse, Robert Margolis, and Sean Ong. 2011. Building-Integrated Photovoltaics (BIPV) in the Residential Sector: An Analysis of Installed Rooftop System Prices. Golden, Colorado, USA. http://www.nrel.gov/docs/fy12osti/53103.pdf.

Juan, Yi-Kai, Peng Gao, and Jie Wang. 2010. "A Hybrid Decision Support System for Sustainable Office Building Renovation and Energy Performance Improvement." Energy and Buildings 42 (3): 290-297. doi:10.1016/j.enbuild.2009.09.006.

Kaklauskas, Arturas, Edmundas Kazimieras Zavadskas, and Saulius Raslanas. 2005. "Multivariant Design and Multiple Criteria Analysis of Building Refurbishments." Energy and Buildings 37 (4): 361-372. doi:10.1016/j.enbuild.2004.07.005.

Lippert, John. 2009. "Induction Lighting: An Old Lighting Technology Made New Again." ENERGY. http://energy.gov/energysaver/articles/induction-lighting-old-lighting-technologymade-new-again.

Long Ni, Wei Song, Fancheng Zeng, and Yang Yao. 2011. "Energy Saving and Economic Analyses of Design Heating Load Ratio of Ground Source Heat Pump with Gas Boiler as Auxiliary Heat Source." In 2011 International Conference on Electric Technology and Civil Engineering (ICETCE), 1197-1200. IEEE. doi:10.1109/ICETCE.2011.5775205.

Matthews, HS, Gyorgyi Cicas, and JL Aguirre. 2004. "Economic and Environmental Evaluation of Residential Fixed Solar Photovoltaic Systems in the United States." Journal of Infrastructure Systems, no. September: 105-110. http://ascelibrary.org/doi/abs/10.1061/(ASCE)1076-0342(2004)10:3(105).

Narendran, N., and Y. Gu. 20k05. "Life of LED-Based White Light Sources." Journal of Display Technology 1 (1): 167-171. doi:10.1109/JDT.2005.852510.

NREL. 2010. "National Solar Radiation Data Base." National Renewable Energy Laboratory. http://rredc.nrel.gov/solar/old_data/nsrdb/.

O’Donnell, J., E. Morrissey, M. Keane, and B. O Gallachoir. 2005. "Reducing Building Operational Cost through Environmental Effectiveness Ratios." In Ninth International 
IBPSA Conference, 883-890. Montréal, Canada.

Pendharkar, Parag C., and Gary J. Koehler. 2007. "A General Steady State Distribution Based Stopping Criteria for Finite Length Genetic Algorithms." European Journal of Operational Research 176 (3): 1436-1451. doi:10.1016/j.ejor.2005.10.050.

Reed, Patrick, Barbara Minsker, and David E. Goldberg. 2000. "Designing a Competent Simple Genetic Algorithm for Search and Optimization." Water Resources Research 36 (12): 3757-3761. doi:10.1029/2000WR900231.

Roberts, By L Michael. 2010. "Magnetic Induction Lights vs. LED Lights." Indulux Technologies Inc. http://www.induluxtech.com/Induction Lights Vs LED Lights - InduLuxTech.pdf.

RSMeans. 2013. RSMeans Building Construction Cost Data. Edited by Philip R. Waier. 70th ed. RSMeans.

Ryckaert, W.R., K.A.G. Smet, I.A.A. Roelandts, M. Van Gils, and P. Hanselaer. 2012. "Linear LED Tubes versus Fluorescent Lamps: An Evaluation." Energy and Buildings 49: 429-436. http://www.sciencedirect.com/science/article/pii/S037877881200134X.

Simmons, Brian, Matthias H Y Tan, C F Jeff Wu, Youngdong Yu, and Godfried Augenbroe. 2013. "Finding the Cost-Optimal Mix of Building Energy Technologies That Satisfies a Set Operational Energy Reduction Target." In 13th Conference of International Building Performance Simulation Association, 1852-1859. Chambéry, France.

Thierens, D., D.E. Goldberg, and A.G. Pereira. 1998. "Domino Convergence, Drift, and the Temporal-Salience Structure of Problems." 1998 IEEE International Conference on Evolutionary Computation Proceedings. IEEE World Congress on Computational Intelligence. IEEE, 535-540. doi:10.1109/ICEC.1998.700085.

Tuhus-Dubrow, Daniel, and Moncef Krarti. 2010. "Genetic-Algorithm Based Approach to Optimize Building Envelope Design for Residential Buildings." Building and Environment 45 (7). Elsevier Ltd: 1574-1581. doi:10.1016/j.buildenv.2010.01.005.

USDOE. 2013. "The QUick Energy Simulation Tool.” eQuest. U.S. Department of Energy. http://www.doe2.com/equest/.

VonNeida, Bill, Dorene Maniccia, and Allan Tweed. 2001. "An Analysis of the Energy and Cost Savings Potential of Occupancy Sensors for Commercial Lighting Systems." Journal of the Illuminating Engineering Society 30 (2): 111-125.

WBCSD. 2009. Energy Efficiency in Buildings - Transforming the Market. The World Business Council for Sustainable Development. http://www.wbcsd.org/transformingthemarketeeb.aspx.

Whitestone Research. 2013. Facility Maintenance and Repair Cost Reference 2013-2014. 18th Editi. Washington, DC: Whitestone Research, The Global Standard in Facility Cost Forecasting. http://secure.whitestoneresearch.com/products/view/FAC-MAR-2013-2014PDF. 
Zhang, Rui, Fei Liu, Angela Schoergendorfer, Youngdeok Hwang, Young M Lee, and Jane L Snowdon. 2013. "Optimal Selection of Building Components Using Sequential Design via Statistical Surrogate Models." In 13th Conference of International Building Performance Simulation Association, 2584-2592. Chambéry, France. 
Table 1. Sample input data of building characteristics

\begin{tabular}{|c|c|}
\hline Description & Building characteristics \\
\hline Building area & 3575 square feet \\
\hline $\begin{array}{l}\text { Building envelop (roof } \\
\text { surfaces) }\end{array}$ & $\begin{array}{l}\text { Wood advanced frame } 24 \text { " with dark brown shingles roofing and } \\
\text { R-19 batt. }\end{array}$ \\
\hline $\begin{array}{l}\text { Building envelop (above } \\
\text { grade walls) }\end{array}$ & $\begin{array}{l}\text { 8" CMU with brick exterior finishing, perlite filling, and R-6 wd } \\
\text { furred insulation. }\end{array}$ \\
\hline Building infiltration & $1.36 \mathrm{ACH}$ for perimeter and core ${ }^{*}$ \\
\hline Building interior construction & $\begin{array}{l}\text { Lay-in acoustic tiles flooring with R-19 batt, wood standard } \\
\text { framing with no board insulation, and mass interior walls. }\end{array}$ \\
\hline Doors & $\begin{array}{l}7^{\prime} \times 6^{\prime} \text { air-lock entry with single bronze } 1 / 8 \text { in. glass in the north } \\
\text { side of the building, } 7{ }^{\prime} \times 6^{\prime} \text { door with single } 1 / 8 \text { in bronze glass in } \\
\text { the south side of the building, and two } 7^{\prime} \times 66^{\prime} \text { opaque doors with } \\
\text { steel hollow core. }\end{array}$ \\
\hline Windows & $\begin{array}{l}30 \% \text { single bronze } 1 / 8 \text { in glass in north, east, and west sides of } \\
\text { the building. }\end{array}$ \\
\hline Building operation schedule & 24 hours \\
\hline Allocation of building activities & $\begin{array}{l}31.9 \% \text { lobby, } 6.8 \% \text { office, } 13.1 \% \text { mechanical and electrical room, } \\
26.6 \% \text { rest rooms, } 12.2 \% \text { storage, and } 9.4 \% \text { retail sales. }\end{array}$ \\
\hline Temperature set and airflow & $\begin{array}{l}68^{\circ} \mathrm{F} \text { cooling, and } 72^{\circ} \mathrm{F} \text { heating, and minimum design flow of } 0.5 \\
\mathrm{cfm} / \mathrm{ft}^{2} \text {. }\end{array}$ \\
\hline
\end{tabular}


Table 2. Building utility and discount rates

\begin{tabular}{|c|c|}
\hline Description & Rate \\
\hline Average electricity billing rate & $0.1 \$ / \mathrm{KWH}$ \\
\hline Average gas billing rate & $0.94 \$ /$ therm \\
\hline Average water billing rate & $0.01 \$ /$ Gallon \\
\hline Discount rate & $2 \%$ \\
\hline Escalation in electricity rates & $0.7 \% *$ \\
\hline Escalation in natural gas rates & $1.6 \%{ }^{*}$ \\
\hline
\end{tabular}


Table 3. Sample input data of building fixtures and equipment

\begin{tabular}{|c|c|c|c|c|c|}
\hline \multicolumn{2}{|c|}{$\begin{array}{c}\text { Building fixture or } \\
\text { equipment }\end{array}$} & \multicolumn{4}{|c|}{ Input Data } \\
\hline $\begin{array}{c}\text { Decision } \\
\text { variable } \\
\text { original } \\
\text { value }\end{array}$ & Location & $\begin{array}{c}\text { Feasible } \\
\text { Alternati } \\
\text { ves }\end{array}$ & Description & $\begin{array}{l}\text { Number of } \\
\text { fixtures or } \\
\text { equipment }\end{array}$ & $\begin{array}{c}\text { Working } \\
\text { hours } \\
\text { per day }\end{array}$ \\
\hline$X_{1}^{1}=1$ & $\begin{array}{l}\text { Men's } \\
\text { bathroom } \\
\text { - Set } 2\end{array}$ & $\begin{array}{l}2 \\
\ldots \\
17\end{array}$ & $\begin{array}{l}\text { Square fluorescent fixture with } 2 \\
\text { T12 U-shaped lamps of } 34 \text { Watts } \\
\text { and } 2279 \text { lumens } \\
\text { Square fluorescent fixture with } 2 \\
\text { T8 U-shaped lamps of } 28 \text { Watts } \\
\text { and } 2265 \text { lumens } \\
\ldots . \\
\text { Square fluorescent fixture with } 2 \\
\text { T8 U-shaped lamps of } 40 \text { Watts } \\
\text { and } 3050 \text { lumens }\end{array}$ & 4 & 24 \\
\hline & & $\ldots$ & $\ldots$ & & \\
\hline$X_{4}^{1}=1$ & $\begin{array}{l}\text { Building } \\
\text { HVAC } \\
\text { System \# } \\
1 \\
\text { (cooling } \\
3.5 \text { ton \& } \\
\text { heating } \\
100 \\
\text { KBTUs) }\end{array}$ & 2 & $\begin{array}{l}\text { Electric HVAC system (EER 8.9, } \\
\text { COP 2) } \\
\text { Ground-source heat pump (EER } \\
\text { 16, COP 4) } \\
\text { Gas Energy Star rated HVAC } \\
\text { system (EER 12.6, AFUE 0.95) } \\
\text { Electric Energy Star rated HVAC } \\
\text { system (EER 12.6, COP 3) }\end{array}$ & 2 & 24 \\
\hline$X_{5}^{1}=1$ & $\begin{array}{l}\text { Building } \\
\text { water } \\
\text { heater } \\
\text { (60 } \\
\text { gallons) }\end{array}$ & $\begin{array}{l}1 \\
2\end{array}$ & $\begin{array}{l}\text { Gas Water heater (TE 0.8) } \\
\text { Energy-star rated gas water } \\
\text { heater (TE 0.90) } \\
\text { Energy-star rated electrical } \\
\text { water heater (EF 2.4) } \\
\text { On-demand gas water heater } \\
\text { (EF 0.9) }\end{array}$ & 1 & 24 \\
\hline$X_{7}^{1}=1$ & $\begin{array}{c}\text { Men's } \\
\text { bathroom } \\
\text { - hand } \\
\text { dryers }\end{array}$ & $\begin{array}{l}2 \\
3 \\
\ldots\end{array}$ & $\begin{array}{l}\text { Hand dryer - } 2300 \text { Watts and } 30 \\
\text { sec drying time } \\
\text { Hand dryer - } 1100 \text { Watts and } 12 \\
\text { second drying time } \\
\text { Hand dryer - } 1100 \text { Watts and } 15 \\
\text { second drying time } \\
\quad \ldots .\end{array}$ & 4 & Per use \\
\hline$X_{12}^{2}=1$ & $\begin{array}{l}\text { Women's } \\
\text { bathroom } \\
\text { - toilets }\end{array}$ & 2 & $\begin{array}{l}\text { Electronic flushing toilet with } 3.5 \\
\text { gallons per flush } \\
\text { Electronic flushing toilet with } 1.6 \\
\text { gallons per flush } \\
\text { Electronic flushing toilet with } \\
1.28 \text { gallons per flush }\end{array}$ & 10 & Per use \\
\hline
\end{tabular}


Table 4 Recommended replacements of interior lighting bulbs for solution (a)

\begin{tabular}{|c|c|c|}
\hline Solution & Room & Recommended Replacements \\
\hline$X_{1}^{1}=10$ & $\begin{array}{l}\text { Men's bathroom } \\
\text { set \# } 1\end{array}$ & $\begin{array}{l}\text { Replace } 12 \text { existing T12 U-shaped lamps of } 34 \text { Watts, } 2279 \\
\text { lumens, and } 18,000 \text { hours life expectance with } 12 \text { T8 U- } \\
\text { shaped lamps of } 32 \text { Watts, } 2253 \text { lumens, and } 30,000 \text { hours } \\
\text { life expectancy. }\end{array}$ \\
\hline$X_{1}^{2}=56$ & $\begin{array}{l}\text { Men's bathroom } \\
\text { set \# } 2\end{array}$ & $\begin{array}{l}\text { Replace } 16 \text { existing longitudinal T12 lamps of } 34 \text { Watts, } \\
2279 \text { lumens, and } 20,000 \text { hours life expectancy with } 16 \\
\text { longitudinal T8 lamps of } 25 \text { Watts, } 2280 \text { lumens, and } 40,000 \\
\text { hours life expectancy. }\end{array}$ \\
\hline$X_{1}^{3}=10$ & $\begin{array}{l}\text { Women's } \\
\text { bathroom set \# } 1\end{array}$ & Same recommendation at men's bathroom set \# 1 \\
\hline$X_{1}^{4}=56$ & $\begin{array}{l}\text { Women's } \\
\text { bathroom set \# } 2\end{array}$ & Same recommendation at men's bathroom set \# 2 \\
\hline$X_{1}^{5}=10$ & Family bathroom & $\begin{array}{l}\text { Same recommendation at men's bathroom set \# } 1 \text { for } 2 \text { T12 } \\
\text { U-shaped lamps }\end{array}$ \\
\hline$X_{1}^{6}=1$ & $\begin{array}{l}\text { Mechanical room } \\
\text { set \# } 1\end{array}$ & Keep existing light bulb \\
\hline$X_{1}^{7}=56$ & $\begin{array}{l}\text { Mechanical room } \\
\text { set \# } 2\end{array}$ & $\begin{array}{l}\text { Same recommendation at men's bathroom set \# } 2 \text { for } 6 \\
\text { longitudinal T12 lamps }\end{array}$ \\
\hline$X_{1}^{8}=37$ & $\begin{array}{l}\text { Travel } \\
\text { information room } \\
\text { set \# } 1\end{array}$ & $\begin{array}{l}\text { Replace } 4 \text { existing longitudinal T12 lamps of } 20 \text { Watts, } 1200 \\
\text { lumens, and } 18,000 \text { hours life expectancy with longitudinal } \\
\text { T5 lamps of } 14 \text { Watts, } 1269 \text { lumens, and } 20,000 \text { hours life } \\
\text { expectancy. }\end{array}$ \\
\hline$X_{1}^{9}=54$ & $\begin{array}{l}\text { Travel } \\
\text { information room } \\
\text { set \# } 2\end{array}$ & $\begin{array}{l}\text { Replace } 10 \text { existing longitudinal T12 lamps of } 25 \text { Watts, } \\
1950,18,000 \text { hours life expectancy with longitudinal T8 } \\
\text { lamps of } 25 \text { Watts, } 2280 \text { lumens, and } 40,000 \text { hours life } \\
\text { expectancy. }\end{array}$ \\
\hline$X_{1}^{10}=9$ & Lobby set \# 1 & $\begin{array}{l}\text { Replace } 36 \text { existing T12 U-shaped lamps of } 34 \text { Watts, } 2279 \\
\text { lumens, and } 18,000 \text { hours life expectance with T8 U-shaped } \\
\text { lamps of } 28 \text { Watts, } 2380 \text { lumens, and } 30,000 \text { hours life } \\
\text { expectancy. }\end{array}$ \\
\hline$X_{1}^{11}=56$ & Storage 1 & $\begin{array}{l}\text { Same recommendation at men's bathroom set \# } 2 \text { for } 2 \\
\text { longitudinal T12 lamps }\end{array}$ \\
\hline$X_{1}^{12}=56$ & Storage 2 & $\begin{array}{l}\text { Same recommendation at men's bathroom set \# } 2 \text { for } 2 \\
\text { longitudinal T12 lamps }\end{array}$ \\
\hline
\end{tabular}


Table 5 Recommended replacements of plumbing fixtures for solution (a)

\begin{tabular}{|c|c|c|c|}
\hline Solution & Room & Fixture & Recommended Replacements \\
\hline$X_{10}^{1}=1$ & Men's bathroom & Faucet & Keep existing water faucets \\
\hline$X_{11}^{1}=2$ & Men's bathroom & Urinal & $\begin{array}{l}\text { Replace existing urinal with electronic flush urinal of } \\
0.125 \text { gallons per flush }\end{array}$ \\
\hline$X_{12}^{1}=3$ & Men's bathroom & Toilet & $\begin{array}{l}\text { Replace existing water toilets with Electronic flushing } \\
\text { toilet of } 1.28 \text { gallons per flush }\end{array}$ \\
\hline$X_{10}^{2}=1$ & Women's bathroom & Faucet & Keep existing water faucets \\
\hline$X_{12}^{2}=3$ & Women's bathroom & Toilet & $\begin{array}{l}\text { Replace existing water toilets with Electronic flushing } \\
\text { toilet of } 1.28 \text { gallons per flush }\end{array}$ \\
\hline$X_{10}^{3}=1$ & Family bathroom & Faucet & Keep existing water faucets \\
\hline$X_{12}^{3}=3$ & Family bathroom & Toilet & $\begin{array}{l}\text { Replace existing water toilets with Electronic flushing } \\
\text { toilet of } 1.28 \text { gallons per flush }\end{array}$ \\
\hline
\end{tabular}




\section{List of Figures}

Figure 1. Optimization Model Development Phases

Figure 2. Decision Variables Chromosome

Figure 3. LCC of building fixture, equipment, or sustainability measure $X_{j}^{i}$

Figure 4. Model implementation

Figure 5. Progress of the optimization computations and the termination condition

Figure 6. Sample database for interior light bulbs

Figure 7. Sample database for solar panels

Figure 8. Sample database for solar inverters

Figure 9. Results of minimizing life-cycle cost of the rest area building

Figure 10. Energy cost of the rest area building before and after minimizing life-cycle cost for solution (a) 


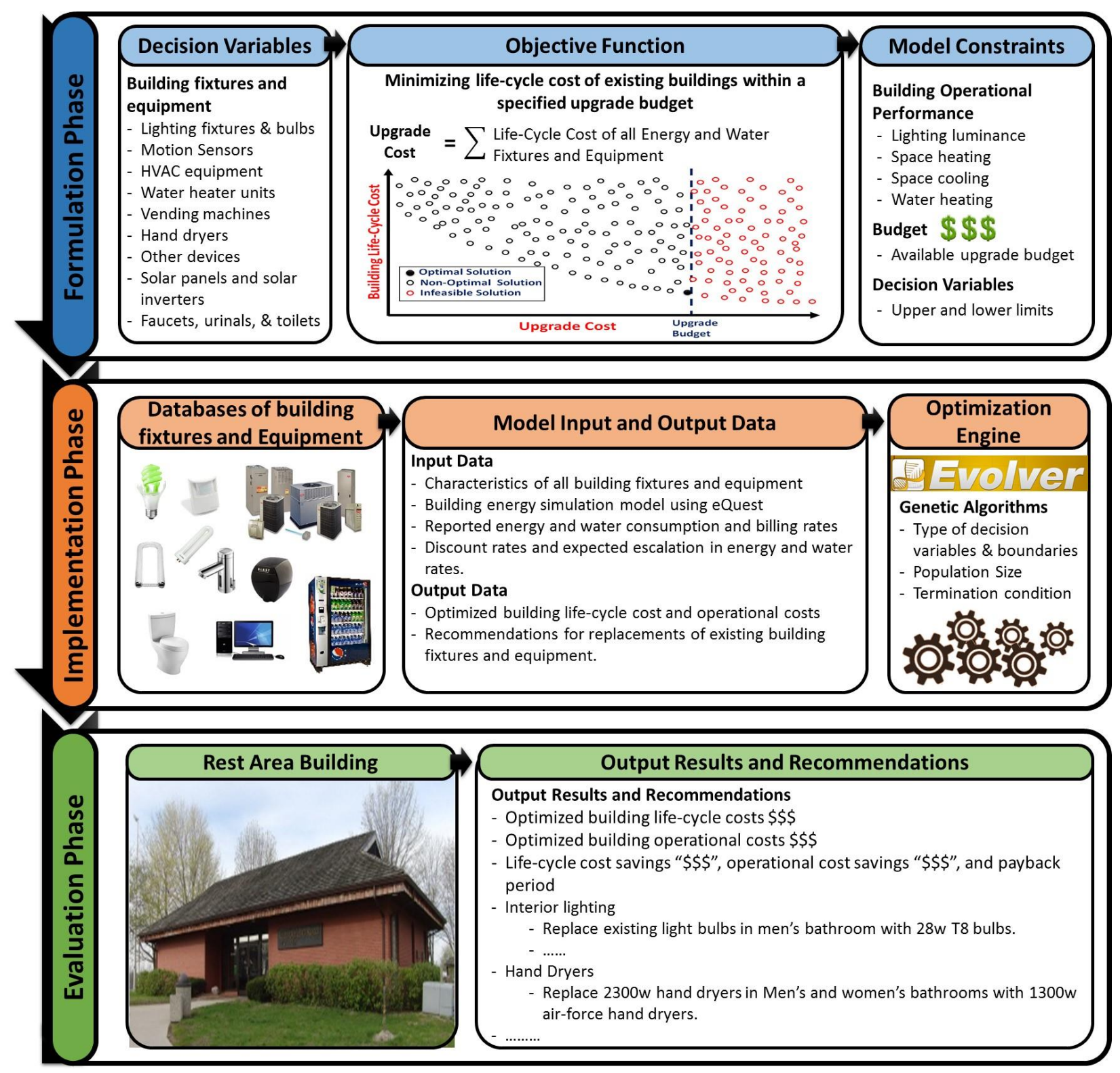




Combinations of light
bulbs and fixtures
$X_{J}^{i}$ : An integer decision variable that represents the selection of building fixture or equipment $X_{j}$ in building location $i$ from a
set of feasible alternatives
$N_{j}:$ Number of locations for building fixture or equipment $X_{j}$
$X_{R E}:$ An integer decision variable which identify the percentage of renewable energy that need to be generated at the building
site such 30\% of the annual electricity demand.




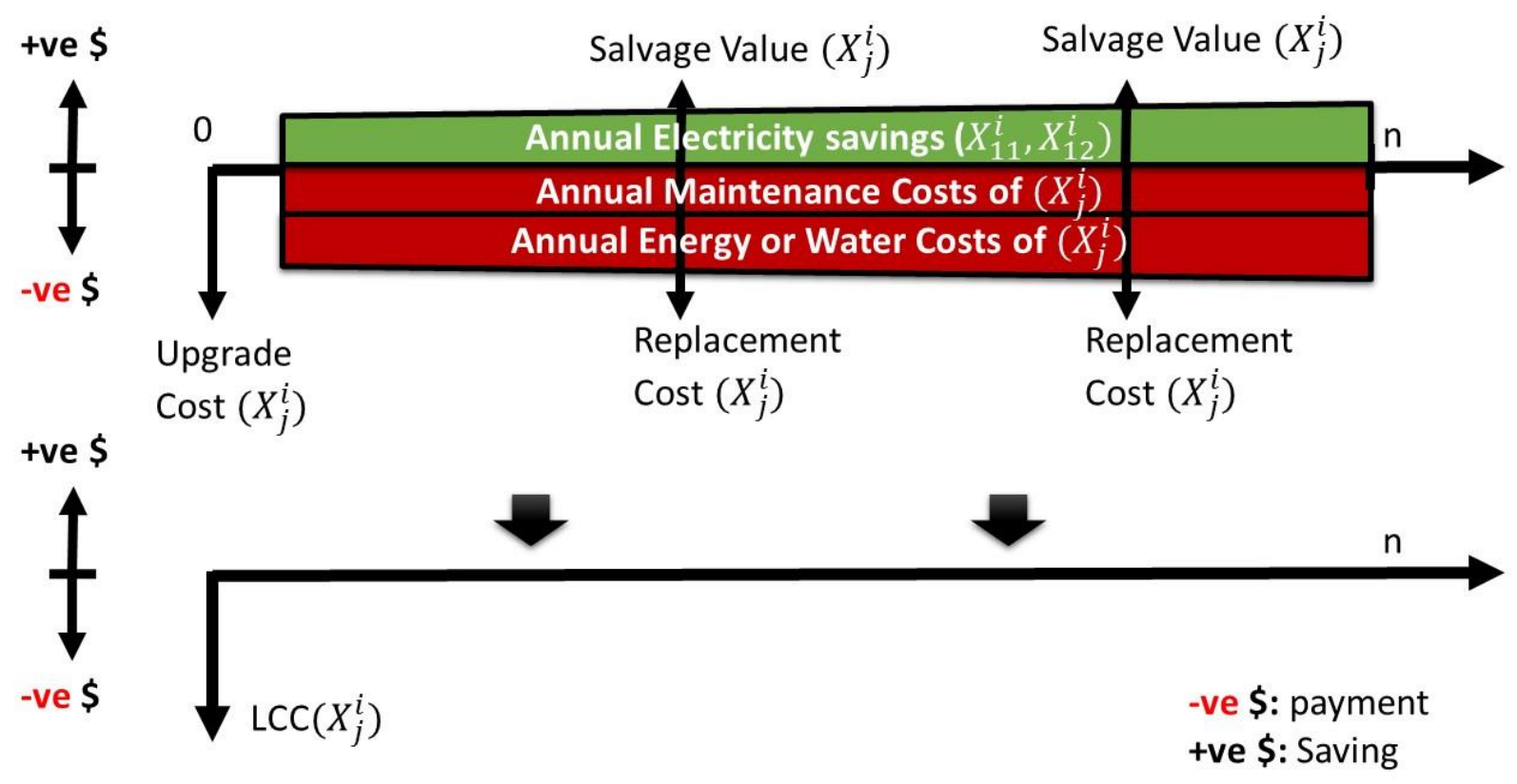




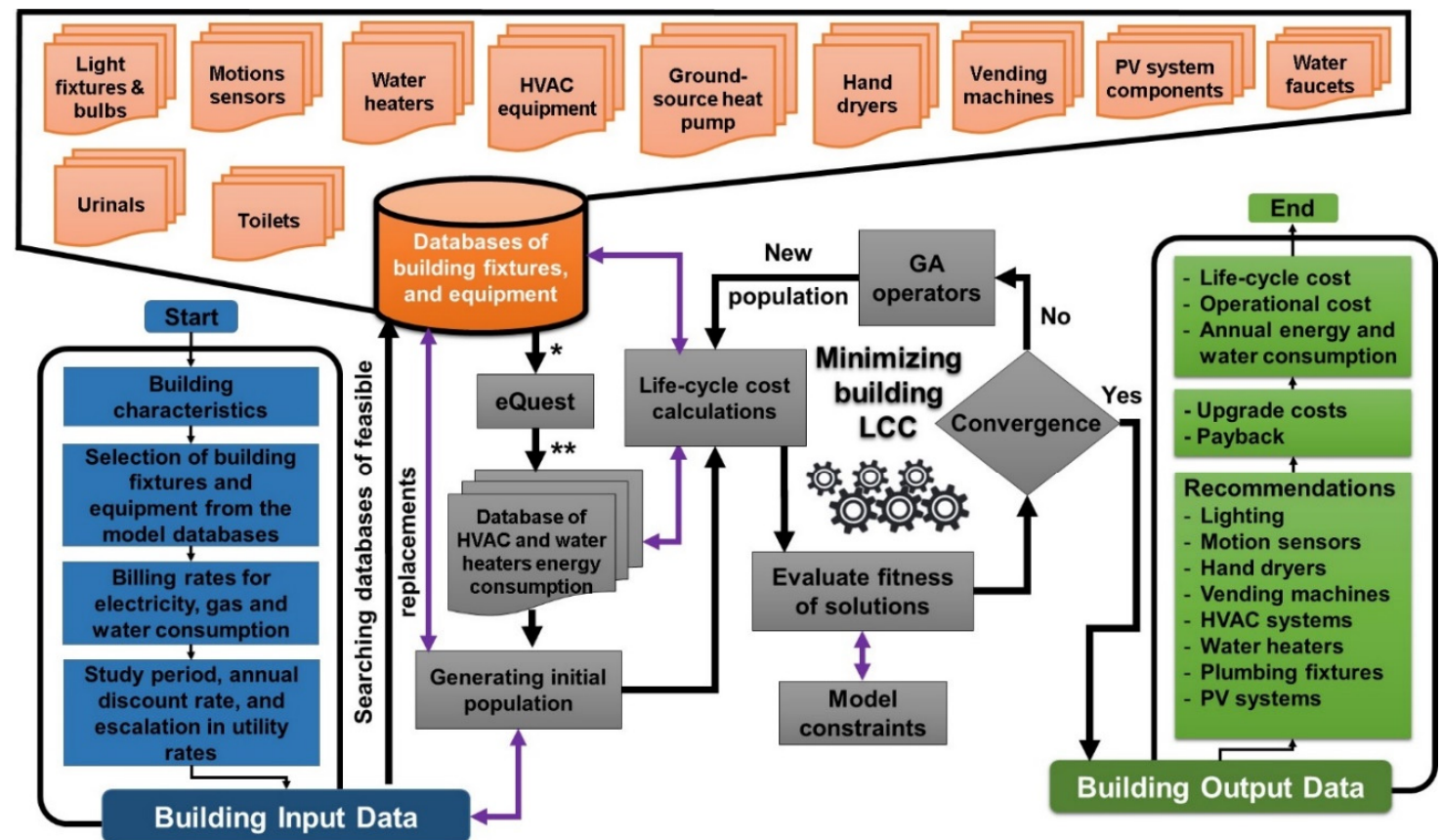

* Calculating energy consumption of feasible HVAC systems and water heaters

** Storing the calculated energy consumption of HVAC systems and water heaters in a database 


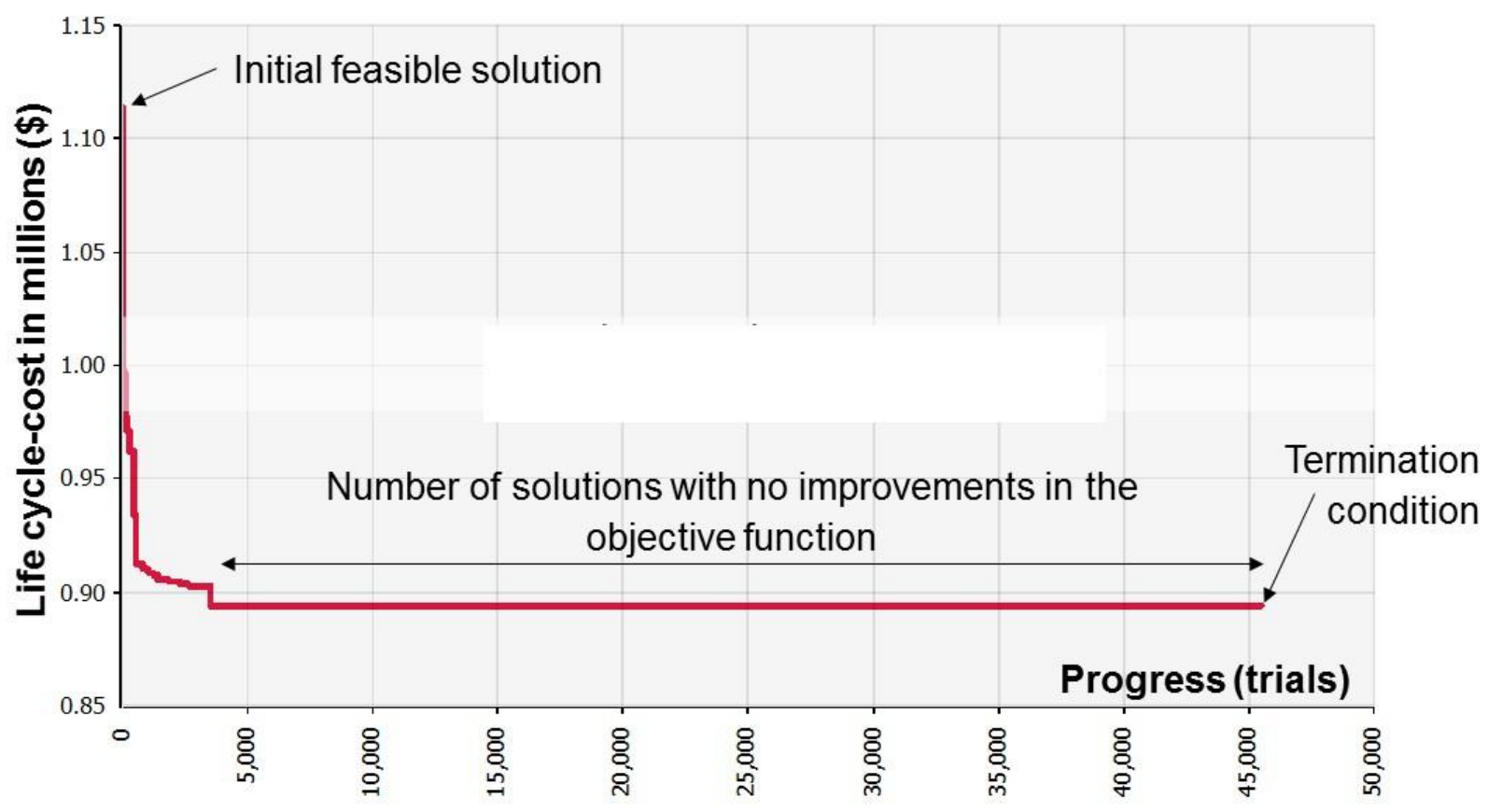




\begin{tabular}{|c|c|c|c|c|c|c|c|c|c|c|c|c|c|}
\hline \multicolumn{14}{|c|}{ Lamp Characteristics } \\
\hline \multicolumn{9}{|c|}{ General Product Characteristics } & \multicolumn{3}{|c|}{ Cost Data } & \multirow{2}{*}{\begin{tabular}{|c|} 
Energy \\
Characteristics \\
Consumption \\
(Watt)
\end{tabular}} & \multirow{2}{*}{\begin{tabular}{|c}
$\begin{array}{c}\text { Physical } \\
\text { Properties }\end{array}$ \\
Length (ft)
\end{tabular}} \\
\hline $\begin{array}{l}\text { Lamp } \\
\text { ID \# }\end{array}$ & $\begin{array}{c}\text { Fixture } \\
\text { group ID } \\
\#\end{array}$ & $\begin{array}{l}\text { Brand } \\
\text { name }\end{array}$ & Model name & $\begin{array}{l}\text { Lamp } \\
\text { Type }\end{array}$ & $\begin{array}{c}\text { Mean } \\
\text { Lumens } \\
\text { (Lumens) }\end{array}$ & $\begin{array}{c}\text { Color } \\
\text { Temperature } \\
\text { (Kelvin) }\end{array}$ & $\begin{array}{c}\text { Color } \\
\text { Rendering } \\
\text { Index (CRI) }\end{array}$ & $\begin{array}{l}\text { Life } \\
\text { Expectancy } \\
\text { (hours) }\end{array}$ & $\begin{array}{l}\text { Lamp } \\
\text { Cost } \\
\text { (\$) }\end{array}$ & $\begin{array}{c}\text { Installation } \\
\text { Cost }(\$)\end{array}$ & $\begin{array}{c}\text { Matenience } \\
\text { Cost }(\$)\end{array}$ & & \\
\hline 0 & 0 & None & None & T8 & 0 & 0 & 0 & 0 & $\$ 0$ & $\$ 0$ & $\$ 0$ & 0 & 0 \\
\hline 1 & 4 & Philips & F32T8/TL950 & T8 & 1860 & 5000 & 98 & 20000 & $\$ 7$ & $\$ 0$ & $\$ 0$ & 32 & 4 \\
\hline 2 & 4 & Philips & F32T8/TL850/ALTO & T8 & 2710 & 5000 & 82 & 36000 & $\$ 3$ & $\$ 0$ & $\$ 0$ & 32 & 4 \\
\hline 3 & 4 & Philips & F32T8/TL741/ALTO & T8 & 2660 & 4100 & 78 & 36000 & $\$ 2$ & $\$ 0$ & $\$ 0$ & 32 & 4 \\
\hline 4 & 9 & Sylvania & $\mathrm{FB} 34 / \mathrm{CW} / 6 / \mathrm{SS} / \mathrm{ECO}$ & $\mathrm{T} 12$ & 2279 & 4200 & 62 & 18000 & $\$ 10$ & $\$ 0$ & $\$ 0$ & 34 & U-Shape \\
\hline 5 & 9 & Sylvania & FBO28/841/XP/SS/ECO & T8 & 2265 & 4100 & 75 & 26000 & $\$ 16$ & $\$ 0$ & $\$ 0$ & 28 & U-shape \\
\hline 6 & 4 & Sylvania & F34CW/SS/ECO & $\mathrm{T} 12$ & 2279 & 4200 & 62 & 20000 & $\$ 2$ & $\$ 0$ & $\$ 0$ & 34 & 4 \\
\hline 7 & 4 & Sylvania & FO28/841/XP/SS/ECO & T8 & 2725 & 4100 & 85 & 36000 & $\$ 9$ & $\$ 0$ & $\$ 0$ & 28 & 4 \\
\hline 8 & 2 & Sylvania & F20T12/CW $20 W$ & $\mathrm{~T} 12$ & 1200 & 4200 & 62 & 18000 & $\$ 2$ & $\$ 0$ & $\$ 0$ & 20 & 2 \\
\hline 9 & 2 & Sylvania & FO17/741/ECO & T8 & 1325 & 4100 & 75 & 20000 & $\$ 6$ & $\$ 0$ & $\$ 0$ & 17 & 2 \\
\hline 10 & 4 & Philips & 30T12/CW/RS/EW, ALTC & $\mathrm{T} 12$ & 1950 & 4100 & 62 & 18000 & $\$ 4$ & $\$ 0$ & $\$ 0$ & 25 & 4 \\
\hline
\end{tabular}




\begin{tabular}{|c|c|c|c|c|c|c|c|c|c|c|c|c|c|c|c|c|c|c|}
\hline \multicolumn{19}{|c|}{ Solar Panels Characteristics } \\
\hline \multicolumn{3}{|c|}{ Product Characteristics } & \multirow{2}{*}{\begin{tabular}{|c|} 
Time \\
$\begin{array}{c}\text { Life } \\
\text { (years) }\end{array}$ \\
\end{tabular}} & \multicolumn{2}{|c|}{ Cost } & \multicolumn{13}{|c|}{ Energy Characteristics } \\
\hline 1D & Brand name & Model I & & $\begin{array}{c}\text { Solar panel } \\
\text { cost (\$) }\end{array}$ & \begin{tabular}{|} 
Maintenance \\
cost (s)
\end{tabular} & $\begin{array}{c}\text { Nominal } \\
\text { Maximum } \\
\text { Power (Pmax) }\end{array}$ & Efficiency & $\begin{array}{c}\text { Maximum } \\
\text { power } \\
\text { voltage(Vpm) }\end{array}$ & $\begin{array}{l}\text { Maximum power } \\
\text { current(IIp) }\end{array}$ & $\begin{array}{l}\text { Open circuit } \\
\text { voltage(Voc) }\end{array}$ & $\begin{array}{l}\text { Short tircuit } \\
\text { current (Isc) }\end{array}$ & $\begin{array}{l}\text { Short tircuit } \\
\text { current (ISc) }\end{array}$ & $\begin{array}{c}\text { Optitimal cell } \\
\text { arrangement ti } \\
\text { series }\end{array}$ & 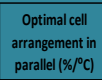 & 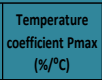 & \begin{tabular}{|c|} 
Temperature \\
coefficent Voc \\
$\left.(\% \%)^{\circ} \mathrm{C}\right)$
\end{tabular} & $\begin{array}{c}\text { Normal } \\
\text { operating cell } \\
\text { temperature }\end{array}$ & \begin{tabular}{|} 
Temperature \\
coefficient ts
\end{tabular} \\
\hline 1 & Sharp & ND-240aCJ & 30 & $\$ 288$ & \$o & 250 & $15.54 \%$ & 30.1 & 8.3 & 37.2 & 8.87 & 7.19 & 6 & 10 & $-0.43 \%$ & $-0.34 \%$ & 45 & $0.07 \%$ \\
\hline 2 & csl & CS6P-235Px & 30 & $\$ 186$ & $\$ 0$ & 235 & $14.61 \%$ & 29.8 & 7.9 & 36.9 & 8.46 & 7.19 & 6 & 10 & $-0.43 \%$ & $-0.34 \%$ & 45 & $0.07 \%$ \\
\hline 3 & Canadian Solar & CS6P-245P & 30 & $\$ 228$ & $\$ 0$ & 245 & $15.23 \%$ & 30 & 8.17 & 37.1 & 8.74 & 7.19 & 6 & 10 & $.0 .43 \%$ & $.0 .34 \%$ & 45 & $0.07 \%$ \\
\hline 4 & csl & CS6P-250P & 30 & $\$ 238$ & $\$ 0$ & 250 & $15.54 \%$ & 30.1 & 8.3 & 37.2 & 8.87 & 7.19 & 6 & 10 & $-0.43 \%$ & $-0.34 \%$ & 45 & $0.07 \%$ \\
\hline 5 & Hyundai & His-255MG & 30 & $\$ 245$ & $\$ 0$ & 255 & $15.80 \%$ & 30.8 & 8.3 & 37.7 & 8.8 & 7.19 & 6 & 10 & $-0.45 \%$ & $-0.33 \%$ & 46 & $0.03 \%$ \\
\hline 6 & Canadian Solar & CS6P 250M & 30 & $\$ 393$ & $\$ 0$ & 250 & $15.54 \%$ & 30.4 & 8.22 & 37.5 & 8.74 & 7.19 & 6 & 10 & $-0.45 \%$ & $-0.35 \%$ & 46 & $0.06 \%$ \\
\hline
\end{tabular}




\begin{tabular}{|c|c|c|c|c|c|c|c|c|c|c|c|c|c|c|c|c|c|c|c|c|}
\hline \multicolumn{21}{|c|}{ Invertor Characteristics } \\
\hline \multicolumn{3}{|c|}{ Product Characteristics } & \multirow{2}{*}{$\begin{array}{c}\text { Time } \\
\begin{array}{c}\text { Life } \\
\text { (years) }\end{array} \\
\end{array}$} & \multicolumn{2}{|c|}{ cost } & \multicolumn{15}{|c|}{ Energy Characteristics } \\
\hline $\begin{array}{l}\text { Invertor } \\
\text { ID\# }\end{array}$ & $\begin{array}{c}\text { Invertor bran } \\
\text { name }\end{array}$ & Invertor Model I\# & & $\begin{array}{l}\text { Invertor } \\
\text { cost (\$s) }\end{array}$ & $\left|\begin{array}{c}\text { Maintenance } \\
\text { cost (5) }\end{array}\right|$ & \begin{tabular}{|c|} 
Minimum \\
recommended \\
power (Wp) (watt)
\end{tabular} & $\begin{array}{c}\begin{array}{c}\text { Average } \\
\text { inverter } \\
\text { power (watt) }\end{array} \\
\end{array}$ & $\begin{array}{l}\text { Maximum } \\
\text { recoommenend power } \\
\text { (Wp) (watt) }\end{array}$ & \begin{tabular}{|l} 
MPPT minimum \\
range (v)
\end{tabular} & $\begin{array}{c}\text { MPPT } \\
\text { maximum } \\
\text { range (v) }\end{array}$ & \begin{tabular}{|c|}
$\begin{array}{c}\text { Maximum } \\
\text { input voltage } \\
\text { range (v) }\end{array}$ \\
\end{tabular} & 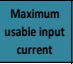 & \begin{tabular}{|c|}
$\begin{array}{c}\text { Nominal } \\
\text { output } \\
\text { power }\end{array}$ \\
\end{tabular} & $\begin{array}{l}\text { Nominal output } \\
\text { current for 110v } \\
\text { or 240v }\end{array}$ & $\begin{array}{l}\text { Power } \\
\text { factor }\end{array}$ & $\begin{array}{l}\text { CEC efficiency at } \\
110 v \text { or } 240 \mathrm{v}\end{array}$ & \begin{tabular}{|c|}
$\begin{array}{c}\text { Max. continous } \\
\text { output voltages } \\
\text { (volt) }\end{array}$
\end{tabular} & $\begin{array}{l}\text { Maximum } \\
\text { efficiency (\%) }\end{array}$ & $\begin{array}{c}\text { Consumption } \\
\text { during } \\
\text { standby }(w)\end{array}$ & $\begin{array}{c}\text { Consumption } \\
\text { during } \\
\text { operation (w) }\end{array}$ \\
\hline 1 & Sharp & N.A. & 20 & $\$ 4,110$ & so & 8500 & 10000 & 11500 & 230 & 500 & 600 & 46.7 & 9995 & 240 & 1 & 0.95 & 240 & $96 \%$ & 1 & 22 \\
\hline 2 & AE & 100Tx & 20 & $\$ 40,508$ & $\$ 0$ & 0 & 7800 & 83333 & & 295 & 600 & 267 & 75000 & 91 & 0.99 & 0.955 & 600 & $97 \%$ & 0 & 0 \\
\hline 3 & Enphase & M215-60-2Ll-522 & 25 & $\$ 194$ & $\$ 0$ & 0 & 240 & 260 & 22 & 36 & 45 & 10.5 & 215 & 0.9 & 0.95 & 0.96 & 240 & $96 \%$ & 0.046 & 0 \\
\hline 4 & Power One & PVI-12.0-1-OUTD-S1 & 20 & $\$ 3,909$ & $\$ 0$ & 0 & 12000 & 13200 & 250 & 470 & 520 & 50 & 13134 & 16 & 0.995 & 0.97 & 528 & $97 \%$ & 0 & 0 \\
\hline 5 & Enphase & M215-60-2L-S23 (Tyco) & 25 & $\$ 129$ & $\$ 0$ & 0 & 240 & 260 & 22 & 36 & 45 & 10.5 & 215 & 0.9 & 0.95 & 0.96 & 240 & $96 \%$ & 0.046 & 0 \\
\hline 6 & Power One & PVI10.0-1-OUTD-S1 & 20 & $\$ 3,791$ & $\$ 0$ & 0 & 10000 & 11000 & 220 & 470 & 520 & 48 & 10945 & 14 & 0.995 & 0.97 & 528 & $97 \%$ & 0 & 0 \\
\hline 7 & Power One & Trio-27.6-TL-OUTD-S1 & 20 & $\$ 6,416$ & $\$ 0$ & 0 & 27600 & 30000 & 520 & 800 & 1000 & 61.8 & 27600 & 36 & 0.995 & 0.975 & 538 & $98 \%$ & 0 & 0 \\
\hline 8 & SMA & ST42 Inverter & 20 & $\$ 20,775$ & $\$ 0$ & 0 & 48000 & 52500 & 250 & 480 & 600 & 180 & 42000 & 101 & 0.99 & 0.995 & 277 & $97 \%$ & 0 & 0 \\
\hline
\end{tabular}




\begin{tabular}{|l|l|l|l|l|l|l|l|l|l|l|}
\hline & \multicolumn{3}{|c|}{ Solution (a) } \\
\hline
\end{tabular}




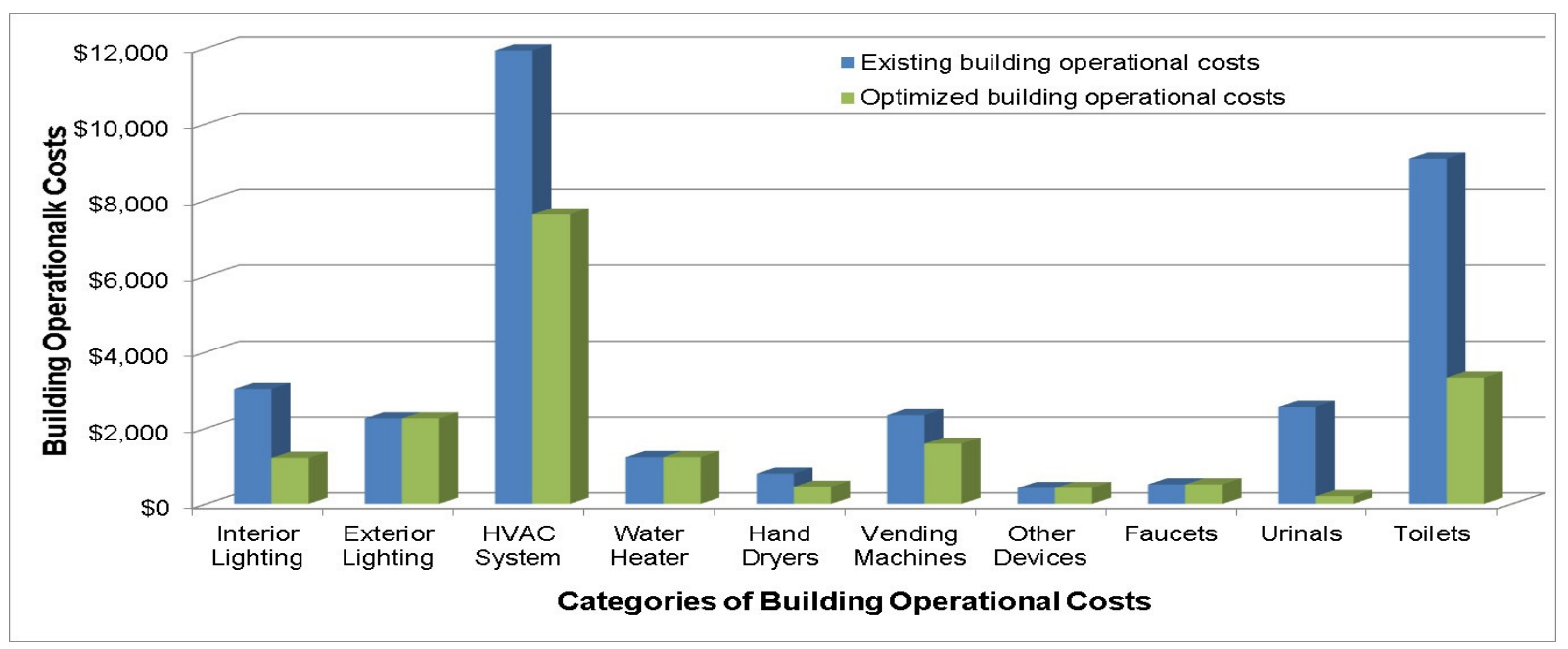




\section{Appendix 1: Notation}

$B L C C$ : building life-cycle cost, $N_{j}$ is number of locations of building fixture or equipment $X_{j}$.

$\operatorname{LCC}\left(X_{j}^{i}\right)$ : LCC of building fixture or equipment $X_{j}^{i}$ which include upgrade costs, annual energy and water costs, escalation in utility costs, maintenance costs, replacement costs, and salvage value.

$n_{j}^{i}$ : number of fixtures of equipment $j$ at location $i$.

$\operatorname{LCC}\left(X_{11}^{i}, X_{12}^{i}\right)$ is life life-cycle cost of photovoltaic system at building roof $(i=1)$ or on the ground $(i=2)$ which include upgrade costs, maintenance costs, replacement costs, annual electricity savings, and salvage value.

$U C\left(X_{j}^{i}\right)$ is upgrade cost of building fixture or equipment $X_{j}^{i}$.

$O C\left(X_{j}^{i}\right)$ is annual operational cost of building fixture or equipment $X_{j}^{i}$ which include energy or water costs and maintenance costs.

$P A$ is present worth factor of an arithmetic gradient series which can be calculated based on annual interest rate, escalation rate in utility bills, and number of years of the study period.

$R C\left(X_{j}^{i}\right)$ is replacement cost of building fixture or equipment $X_{j}^{i}$.

$P F R_{r}$ is present worth of the future replacement cost $r$ of building fixture or equipment $X_{j}^{i}$ which depends on its expected future replacement time and the annual interest rate.

$\mathrm{R}$ is total number of replacements that depends on the expected service life of the building fixture or equipment in years and the duration of the study period $\mathrm{n}$ in years.

$S V\left(X_{j}^{i}\right)$ is salvage value of building fixture or equipment $X_{j}^{i}$. 
$P F S_{r}$ is present worth of the building fixture or equipment salvage value which can be calculated based on annual interest rate and number of years of the study period.

$U C\left(X_{11}^{i}, X_{12}^{i}\right), O C\left(X_{11}^{i}, X_{12}^{i}\right), R C\left(X_{11}^{i}\right), R C\left(X_{12}^{i}\right), S V\left(X_{11}^{i}\right)$, and $S V\left(X_{12}^{i}\right)$ upgrade cost, operational cost, replacement cost of solar panels, replacement cost of inverters, salvage value of solar panels, and salvage value of solar inverters, respectively.

$E S\left(X_{11}^{i}, X_{12}^{i}\right)$ is electricity savings of photovoltaic system $i$.

HDEC: hand dryers electricity consumption in Kilowatt-hour.

$N_{j}$ : number of locations of hand dryers.

$W\left(X_{5}^{i}\right)$ : electricity consumption in kilowatts of hand dryer $X_{5}$ at location $i$ of the building.

$D\left(X_{5}^{i}\right)$ : average drying time in hours of hand dryer $X_{5}^{i}$.

$U P D$ : number of uses per day.

365: the number of days per year to calculate the annual energy consumption of hand dryers.

$B U C$ : building upgrade costs.

$\operatorname{CoolC}\left(E_{4}^{i}\right)$ : the cooling capacity of existing HVAC system $E_{4}$ at location $i$ of the building.

$\mathrm{R}_{c}$ : the allowed percentage reduction of the HVAC $E_{4}^{i}$ cooling capacity.

$\operatorname{CoolC}\left(X_{4}^{i}\right)$ : the cooling capacity of the possible replacement for the HVAC system $E_{4}$ with $X_{4}$ at location $i$ of the building.

$\operatorname{HeatC}\left(E_{4}^{i}\right)$ : the heating capacity of existing HVAC system $E_{4}$ at location $i$ of the building.

$\mathrm{R}_{h}$ : the allowed percentage reduction of the HVAC $E_{4}^{i}$ heating capacity.

$\operatorname{HeatC}\left(X_{4}^{i}\right)$ : the heating capacity of the possible replacement for the HVAC system $E_{4}$ with $X_{4}$ at location $i$ of the building.

$B E C$ : building annual electricity consumption in Kwh.

$A D S I_{i, m}$ : average daily solar insolation in month $m$ at location $i$ of the building based on the tilt and orientation angle of solar panels and location of the building in peak sun hours.

$D_{m}$ : number of days per month $m$. 
$w\left(X_{11}^{i}\right)$ : energy production of single solar panel $X_{11}^{i}$ at location $i$ of the building in watts.

$\mathrm{n}_{11}^{i}$ : number of solar panels at location $i$ of the building.

$t_{m, X_{11}^{i}}$ : derating factor of the daily temperature effect in month $m$ for solar panel $X_{11}^{i}$, on the electricity production of solar panels $X_{11}^{i}$.

$\mathrm{d}$ : derating factor of the dirt and snow effect on the electricity production of solar panels.

$e_{i, X_{12}^{i}}$ : derating factor of the inverter efficiency $X_{12}^{i}$ for converting DC current to AC current at location $i$ of the building.

$w$ : derating factor of $D C$ and $A C$ wiring in a PV system. 